\title{
Komunikasi Antarpribadi Dan Komunikasi Kelompok Tenaga Pengamanan Perambah Hutan Illegal Untuk Mengatasi Perambahan Hutan
}

\author{
Teguh Budiraharjo, Tina Kartika \\ Jurusan Ilmu Komunikasi, Fakultas Ilmu Sosial dan Ilmu Politik, \\ Universitas Lampung. \\ teguh.budi.@fisip.unila.ac.id, tina.kartika@fisip.unila.ac.id
}

\begin{abstract}
ABSTRAK
Permasalahan perambahan hutan, bukan hanya permasalahan lingkungan hidup, juga sudah menjadi masalah yang melibatkan berbagai aspek. Masalah ini dapat dikaji dari sudut pandang, misalnya, sosial, ekonomi, politik dan budaya. Salah satu cara untuk menghindari terjadinya perambahan hutan adalah pemanfaatan media. Media dalam arti sebagai alat untuk menyebarkan informasi. Pemberdayaan komunikasi antarpribadi dan komunikasi kelompok antara tenaga pengamanan perambah hutan illegal dengan perambah hutan dan atau mantan perambah hutan. Temuan dalam penelitian ini adalah adanya peranan komunikasi antarpribadi dan komunikasi kelompok yang dilakukan tenaga pengamanan perambah hutan illegal. Hal ini diawali dari temuan adanya oknum petugas TNBBS memberitahu kepada mantan perambah hutan akan diadakan patroli hutan. Akibatnya para mantan perambah hutan tidak beroperasi di lahan TNBBS Kecamatan Tanggamus. Hal ini menunjukkan bahwa adanya kedekatan antarpribadi dan belajar menyimpang akibat sesuatu yang dipelajari terus menerus. Ketidak seimbangan sikap yang mendorong melakukan penyimpangan yaitu perambahan hutan. Dari temuan ini, maka direkomendasikan agar para pengambil kebijakan, pejabat TNBBS, masyarakat setempat, polisi hutan benarbenar harus komitmen untuk menjaga kawasan TNBBS sebagai kawasan lindung sekaligus sebagai paru-paru dunia.
\end{abstract}

Keywords: Komunikasi antarpribadi, komunikasi kelompok, media, perambahan hutan 


\section{PENDAHULUAN}

\section{Latar Belakang Penelitian}

Taman Nasional Bukit
Barisan Selatan (TNBBS) adalah
kawasan konservasi ketiga di

Sumatera. Ditetapkan sebagai taman

Nasional Pada tahun 1982 melalui surat pernyataan Menteri Pertanian No 7356/Mentan/X/1982 tanggal 14 Oktober 1982 melalui Sk Menteri Kehutanan No. 185/kpts-II/1997 tanggal 31 Maret 1997 statusnya berubah menjadi Balai Taman Nasional Bukit Barisan Selatan. Kawasan ini luasnya kurang lebih 360.000 Ha. (surat pernyataan Menteri Pertanian No 7356/Mentan/X/1982 tanggal 14 Oktober 1982 melalui Sk Menteri Kehutanan No. 185/kpts-II/1997 tanggal 31 Maret 1997)

Banyak permasalahan yang terjadi di Taman Nasional Bukit Barisan Selatan antara lain: perambahan hutan (enroachment), pemantapan/keamanan kawasan, kelestarian sumber daya alam hayati, keterbatasan sumber daya kelembagaan, penebangan liar (illegal logging), perburuan liar seperti harimau, burung dan gajah khas sumatera, konflik satwa dengan manusia, tata batas kawasan dan tata ruang/zonasi yang belum benar-benar mantap. (Deni. 2011).

Untuk menjaga kawasan ini, telah disiagakan satuan petugas pengamanan perambah hutan yang berjumlah 80 orang. Tugas dari pengamanan perambah hutan tersebut adalah menjaga keamanan kawasan tersebut. Namun para petugas pengamanan perambah hutan ini belum mampu menjaga kawasan ini dengan baik. Pada kawasan itu diperkirakan telah ada 800 Kepala keluarga yang secara ilegal merambah hutan di kawasan ini. (Proposal progam Conserving the Bukit Barisan Selatan National Park as a UN World Heritage Site in Sumatra. 2015). Permasalahannya adalah adanya perambah hutan/penggarap hutan tidak resmi di daerah BBS dan masyarakat kecil di desa-desa sekitar BBS. Permasalahan berikutnya adalah mengapa para petugas pengamanan perambah hutan belum dapat melakukan tugasnya dengan baik?. Menindaklanjuti masalah yang terjadi dikawasan tersebut, maka 
perlu keahlian multi disiplin untuk menyelesaikan permasalahan perambah hutan tersebut, salah satu ilmu khusus tersebut adalah komunikasi. Dari latarbelakang inilah diadakan kerjasama antara peneliti (Dosen Jurusan Ilmu Komunikasi) dengan proyek Conserving the Bukit Barisan Selatan National Park as a UN World Heritage Site in Sumatra. Bahasan selanjutnya adalah komunikasi antarpribadi dan komunikasi kelompok tenaga pengamanan perambah hutan illegal. Maka tujuan penelitian ini adalah mengidentifikasi jaringan komunikasi antara perambah hutan dan jaringan komunikasi banyak pihak yang terlibat dalam kegiatan perambah hutan.

\section{KAJIAN PUSTAKA}

Permasalahan yang terjadi di Taman Nasional Bukit Barisan Selatan antara lain: perambahan hutan (enroachment), pemantapan/keamanan kawasan, kelastarian sumber daya alam hayati, keterbatasan sumber daya kelembagaan, penebangan liar (illegal logging), perusakan habitat satwa badak, perburuan liar seperti harimau, burung dan gajah khas sumatera, konflik satwa dengan manusia, tata batas kawasan dan tata ruang/zonasi yang belum benarbenar mantap. Ditambah dengan lemahnya pihak pemerintahan daerah (Deni. 2011) Selanjutnya

Deni menjelaskan bahwa konflik yang terjadi di Desa Tirom Kecamatan Pematang Sawah Kabupaten Tanggamus penyebabnya adalah tata batas kawasan dan tata ruang/zonasi belum benar-benar mantap dan lemahnya pihak pemerintah daerah. Penelitian Deni ini adalah kasus awal yang dapat dijadikan pedoman dalam menetapkan permasalahn berikutnya. Adapun konflik manusia dan hewan, perambahan hutan, penebangan pohon secara illegal ditelah diidentifikasi oleh peneliti-peneliti sebelumnya.

Pemetakan daerah rawan konflik sosial di Kabupaten Tanggamus, yang berjudul Pemetaan Daerah Rawan Konflik Sosial di Kabupaten Tanggamus. 
Pada penelitian Fahmi dan Akbar, adalah penelitian yang melibatkan tenaga penelti yaitu Fami dan Akbar sebagai tenaga profesional (PNS) di Kabupaten Tanggamus. Pada umumnya daerah yang berkonflik adalah daerah yang berbatasan dengan TNBBS. Sama dengan Deni, Fahmi juga memetakan konflik yang terjadi di Kabupaten Tanggamus. Penelitian Fahmi dan Akbar tidak kalah pentingnya pada penelitian ini, yaitu sebagai panduan dalam penelitian ini.

Handoyo dkk, 2011 menjelaskan bagaimana kondisi tenurial yang ada saat ini yang dapat mempengaruhi implementasi REDD+. Analisis dilakukan secara deskriptif kualitatif dengan menggunakan metode (RaTA) yang secara khusus dimodifikasi dan diadaptasi untuk penelitian ini. Analisis terhadap temuan di lapangan memperlihatkan variasi kondisi tenurial yakni: (a) Kabupaten Merangin khususnya dan Provinsi Jambi secara umum relatif memiliki banyak konflik lahan dengan upaya penyelesaian yang dilakukan untuk memperoleh kesepakatan formal, (b)
Kabupaten Berau secara umum dan Desa Long Duhung pada khususnya potensi konflik lahan tidak terlalu besar dengan upaya penyelesaian melalui kesepakatan informal, dan (c) Kondisi tenurial di Taman Nasional Meru Betiri, Jawa Timur lebih terjamin karena status dan batas kawasan yang pasti serta pengakuan masyarakat sekitar atas keberadaan kawasan hutan TNMB. Penelitian ini menyarankan perlunya dilakukan penatabatasan lahan secara partisipatif yang melibatkan para pihak termasuk pemerintah, swasta dan masyarakat sekitar. Handoyo, dkk. 2011

Handoyo, dkk 2011 Menjelaskan bahwa lahan di beberapa taman nasional di Indonesia pada umumnya memiliki konflik dengan masyarakat setempat. Pada tahap-tahap tertentu menyelesaian masalah melibatkan banyak pihak antara lain pihak swasta, pemerintah setempat dan masyarakat setempat. Tahap-tahap penyelesaian masalah pada penelitian Hadoyo ini dapat dijadikan panduan dalam 
menyelesaikan konflik di kawasan

TNBBS ini.

\section{Pengertian, Tujuan dan Fungsi}

\section{Komunikasi}

Komunikasi mempunyai

fungsi yang berbeda-beda. Thomas

M. Scheidel, dalam Mulyana, 2000

:62. mengemukakan bahwa kita berkomunikasi terutama untuk menyatakan dan mendukung identitas diri untuk membangun kontak sosial dengan orang di sekitar kita dan mempengaruhi orang lain, merasa berpikir atau berperilaku yang seperti kita inginkan. Hal tersebut sesuai pengertian komunikasi dari konsep para ahli ; Gerald $R$ Miller : "komunikasi terjadi ketika sumber menyampaikan suatu pesan kepada penerima dengan niat yang disadari untuk mempengaruhi perilaku penerima" dan Everet M Rogers : "Komunikasi adalah proses dimana suatu ide dialihkan dari sumber kepada penerima atau lebih dengan maksud untuk mengubah tingkah laku mereka"

Kajian komunikasi antarpribadi dan komunikasi kelompok yang melahirkan model Komunikasi negosiasi tenaga pengamanan perambah hutan illegal, direncanakan memetakan model komunikasi negoisasi pada tahun berikutnya yaitu 2019 .

\section{METODE PENELITIAN}

Penelitian ini menggunakan pendekatan kualitatif, dengan sumber data primer, yaitu observasi, wawancara kajian pustaka. Adapun Informan pada penelitian ini adalah : 1) Para tenaga pengaman perambah hutan berjumlah 80 orang, 2) Para perambah hutan, berjumalah 800 KK 3) Tenaga perwakilan dari TNBBS. 4) Pejabat dari pemda terkait. Teknik pengambilan informan menggunakan teknik purposive sampling. Teknik Pengumpulan Data digunakan dalam penelitian ini adalah: 1 . Partisipan Observer/pengamatan berperan serta. 2 . Observasi tanpa peran serta, 3. Wawancara mendalam, 4. Studi Dokumentasi. Teknik Analisis Data melalui Pengumpulan data, pengelompokan data dan interpretasi data, serta penarikan kesimpulan (Verifikasi data). 


\section{Komunikasi antarpribadi/personal}

Konsep teori Johari Window,

Wood, Julia T. 1997: 209. menjelaskan bahwa pada diri manusia itu terdiri dari pintu jendela, maksudnya ada dua daun jendela, ketika jendela itu dibuka dan ketika jendela itu ditutup. Johari Window menggambarkan tingkat keterbukaan seseorang yang dibagi dalam empat kuadran, Kuadran-kuadran tersebut sebagai berikut: Open, misal sifat, motivasi dan perasaan. Kita mengetahui kelemahan dan kelebihan diri sendiri begitu juga dengan orang lain. (terbuka pada orang lain, dan orang lain terbuka menilai tentang dirinya). Blind, misal orang mengetahui kita riang, gembira. Padahal sesungguhnya orang lain mengetahui kita tidak sedang riang atau gembira. Maka orang akan berhati-hati kepada orang tersebut. (Artinya ada hal-hal atau bagian yang dia sendiri tahu tapi orang lain tidak). Hidden, saya mengetahui tentang diri saya, dan orang lain tidak perlu mengetahui. Termasuk perilaku dan informasi yang disembunyikan. Orang dengan julukan hidden diperlukan tenaga, pikiran waktu yang berlebih untuk mengunkapkan bagaimana perilaku merokoknya. Unkwon, yang bersangkutan ataupun orang lain tidak mengetahui apapun itu yang sebenarnya. (Merupakan orang tipe paling tertutup. Tidak mau membuka dirinya keluar maupun menerima pendapat/masukan/feedback dari luar). Wawancara yang mendalam dan diperlukan banyak waktu untuk mengetahui perilaku orang yang demikian ini. Para perambah hutan dan para tenaga pengamanan perambah hutan illegal, dikaji dari beberapa konsep johari window ini.

\section{HASIL DAN PEMBAHASAN \\ PENELITIAN}

\section{Gambaran Lokasi Penelitian}

Dari hasil identifikasi wilayah pemukiman penduduk yang berbatasan langsung dengan kawasan Taman Nasional Bukit Barisan (TNBBS) untuk wilayah Kabupaten Tanggamus provinsi Lampung, meliputi 2 wilayah Kecamatan yakni Kecamatan Pematang Sawa yang memiliki 14 desa (pekon), tetapi 
yang berbatasan dengan kawasan TNBBS hanya 5 pekon yakni pekon Pekon Way Nipah, pekon Guring, pekon Tirom, pekon Karang Brak dan pekon Teluk Brak. Sedangkan Kecamatan Semaka yang memiliki 22 desa (pekon) dan yang berbatasan dengan kawasan TNBBS hanya 1 pekon yakni Pekon Sidomulyo.

Dari tujuh pekon yang menjadi wilayah desa penyangga kawasan TNBBS, masing-masing pekon memiliki beberapa wilayah pemukiman milik para perambah hutan yang dinamakan "Talang" dengan dihuni oleh beberapa kepala keluarga (KK) bersifat tidak menetap. Adapun penamaan Talang kebanyakan menggunakan nama asal daerah mereka, sehingga menyerupai sebuah desa "kantong". Adapun yang dimaksud tidak menetap adalah kondisi pemukiman sementara oleh para perambah hutan hanya akan dihuni kembali pada waktu-waktu tertentu saja seperti saat melakukan perawatan tanaman dan saat panen.

Seluruh kawasan perambah tersebut di tanami tanaman Kopi saja, sehingga untuk pemenuhan kebutuhan sehari-hari mereka kebanyak telah dibawa dari daerah asal mereka sebelum memasuki kawasan "Talang" untuk hidup beberapa hari saja.

Dari sepuluh wilayah pemukiman "Talang" sebanyak 4 wilayah talang pada saat dilakukan survey lapangan sedang dalam kondisi kosong (tidak berpenghuni) sementara itu berdasarkan informasi dari lokasi lain bahwa saat ini belum memasuki musim panen kopi, sehingga kunjungan ke lokasi talang hanya bersifat sementara untuk mengetahui kondisi tanamannya saja. Kemudian dengan mempergunakan metode trianggulasi data diperoleh data informan sebanyak 9 (sembilan) orang informan yang bersedia memberikan informasi yang cukup memadai sesuai dengan tujuan penelitian. Adapun informan dari petugas penyuluh perambah hutan diperoleh informan sebanyak 20 (dua puluh) orang informan yang tergabung dalam satuan tugas KPHL Kota Agung Utara. Keterbatasan yang dihadapi di lapangan antara lain dikarenakan banyak pemukiman yang tidak dihuni pada saat dilakukan penelitian, kemudian dari 
beberapa informan sangat tertutup dalam memberikan informasi serta adanya kecurigaan dari mereka terhadap orang luar.

\section{PEMBAHASAN}

Daerah penyangga adalah wilayah yang berada di luar Kawasan Pelestarian Alam, baik sebagai kawasan hutan lain, tanah negara bebas maupun tanah yang dibebani hak yang diperlukan dan mampu menjaga keutuhan Kawasan Pelestarian Alam. Pengelolaan atas daerah penyangga tetap berada di tangan yang berhak, sedangkan caracara pengelolaan harus mengikuti ketentuan yang ditetapkan dalam Peraturan Pemerintah RI No. 68 tahun 1998 tentang Kawasan Suaka Alam dan Kawasan Pelestarian Alam (Penjelasan Undang-Undang RI No.

5 tahun 1990 pasal 16 ayat 2). Dalam kata lain, wilayah/zona penyangga merupakan penamaan perwilayahan secara fungsional karena penamaan ini didasarkan pada fungsi daerah tersebut sebagai pelindung atau penyangga bagi daerah yang lain. Maka dari itu, zona ini dijadikan sebagai tolak ukur terhadap kerusakan daerah yang akan dilestarikan.

Sebagai tindak lanjut seharusnya perlu ketegasan dari pemerintah setempat untuk melarang aktivitas perambahan hutan. Misalnya pada kasus lain, hutan lindung sebelumnya merupakan tempat terpencil, sekarang sudah menjadi kawasan perlu dievaluasi akibat pembangunan pemukiman penduduk. Di kawasan lindung di hutan Mondah di Gabon, sebelah utara Libreville telah kehilangan $40 \%$ wilayahnya selama 80 tahun. Termasuk 24 spesies endemic terancam oleh urbanisasi (Walters, G., Ndjabounda, E. N., Ikabanga, D., Biteau, J. P., Hymas, O., White, L. J. T.,\& Stevart, T. (2016).

\section{Perilaku dan Interaksi Para Perambah Hutan mempengaruhi perambahan Hutan \\ Interaksi yang terjadi dalam masyarakat talang sangat berpengaruh dalam kegiatan perambahan hutan taman nasional. Seringnya masyarakat bertatap muka menyebabkan terjadinya komunikasi yang intens sehingga munculah}


saling mempengaruhi untuk di TNBBS: "Pindah dari kampung melakukan perambahan hutan. karena tidak ada lahan, dan melihat Keyakinan itu digambarkan dengan kawasan itu terbuka jadi ikut-ikutan. wawancara dari informan $1,2,3,4,5,6,7,8$ dan 9 yang menyatakan hal yang sama yaitu kegiatan perambahan dilakukan secara bersama-sama. Tidak ada saling mengajak untuk membuka namun dilakukan karena terbentuknya persepsi untuk ikut melakukan pembukaan lahan di taman nasional. Persepsi itu terbentuk ketika masyarakat saling berinteraksi karena adanya kedekatan secara personal, hingga terjadinya komunikasi antarpribadi diantara mereka. Berikut adalah hasil wawancara tentang pembagian lahan di kawasan TNBBS, salah satu informan yaitu informan 1 menjelaskan: "Tidak ada pembagian, jadi rakus-rakusan. Semau-mau kita mau membuka. Jadi Cuma kita yang tau. Jika sudah ada yang buka, maka kita tidak akan mengganggu lahan tersebut. bebas buka lahan juga dilakukan bersama-sama”. (wawancara 19 Juli 2017)

Selanjutnya informan 1 menjelaskan sebab membuka lahan 
Batas lahan yang dimiliki oleh para perambah yaitu hanya parit kecil sebagai tanda kepemilikan. Mereka mengetahui lahan tersebut milik warga desa dikarenakan ketika membuka lahan dilakukan bersamasama sehingga mereka tahu sama tahu. Dengan kegiatan yang dilakukan bersama-sama tersebut mereka berinteraksi secara intens dan saling melindungi. (Observasi 20-22 Juli 2017).

\section{Komunikasi antarpribadi mantan perambah hutan dengan oknum polisi Hutan}

Berdasarkan observasi, kegiatan masyarakat beraktivitas di Taman Nasional Bukit Barisan Selatan. Meskipun saat ini mereka sudah tidak melakukan perambahan secara besar besaran, namun mereka masih memanfaatkan kawasan hutan untuk memenuhi kebutuhan ternak dan kayu bakar. Mereka masih mengambil rumput dan kayu bakar untuk dimanfaatkan sehari-hari. Ada pula yang memanfaatkan mata air yang terdapat di dalam taman nasional untuk memenuhi kebutuhan air bersih. Mereka diperbolehkan menggunakan air dikarenakan masyarakat pekon Margomulyo masih belum terpenuhi untuk kebutuhan air bersih. Masyarakat Desa Margomulyo masih menggunakan tampungan air hujan untuk kebutuhan mandi, itupun hanya didapatkan ketika musim hujan.

Hubungan antar sesama
mantan perambah saat mereka melakukan perambahan sangatlah erat. Mereka memiliki hubungan intrapersonal yang sangat erat. Komunikasi interpersonal adalah komunikasi antar-perorangan yang bersifat pribadi baik yang terjadi secara langsung (tanpa medium) maupun tidak langsung (melalui medium). Contohnya kegiatan percakapan tatap muka, percakapan melalui telepon, surat menyurat pribadi. Fokus pengamatannya adalah bentuk-bentuk dan sifat hubungan (relationship), percakapan (discourse), interaksi dan karakteristik komunikator.

Hubungan intrapersonal ini terlihat dari cara oknum petugas taman nasional dan mantan 
perambah dalam melakukan komunikasi untuk menghindari razia petugas taman nasional. Hal serupa diungkapkan oleh informan 4,5,6,7 dan 8. Mereka menyebutkan bahwa ketika akan dilakukan razia perambahan hutan, ada oknum petugas memberi tahu agar mereka tidak masuk ke dalam kawasan hutan terlebih dahulu sehingga mereka aman dari razia yang dilakukan. Salah satu informan menjelaskan cara menghidari polisi hutan adalah diberitahu dari tetangga (wawancara 19 Juli 2017). Pernyataan sama juga dari informan 7 , namun dia menyebutkan adapula pemberitahuan melalui telepon oleh sesama mantan perambah untuk menghemat waktu. Sedangkan menurut informan 6, sesama mantan perambah akan memberitahu jika ada petugas yang lewat di depan rumah mereka. Mantan perambah yang melihat petugas akan segera memberitahu temannya.

Hakikat komunikasi adalah proses pernyataan antarmanusia yang dinyatakan adalah pikiran atau perasaan seseorang kepada orang lain dengan menggunakann bahasa sebagai alat penyalurnya. Dalam pergaulan hidup manusia, masingmasing individu satu sama lain beraneka ragam menjadi interaksi, saling mempengaruhi demi kepentingan dan keuntungan pribadi masing-masing. Hubungan interpersonal yang terjadi karena adanya kegiatan secara bersamasama. Ikatan masih kuat di perdesaan juga mendukung kuatnya komunikasi antarpribadi. Mereka terlibat dalam komunikasi bentuk dialog yang berfungsi ganda, masing-masing menjadi pembicara dan pendengar secara bergantian. Dalam proses komunikasi dialogis nampak adanya upaya dari para pelaku komunikasi untuk terjadinya pengertian bersama-sama (mutual understanding) dan empati. Keluarga merupakan tempat berkomunikasi orang tua dan anak, proses transformasi nilai pada perkemsbangan anak. Hubungan intrapersonal juga terjadi di luar lingkup keluarga yaitu tetangga. Hal ini terjadi di Desa Margomulyo, hubungan masyarakat terjalin dengan baik. 
Sebagai data perbandingan, diambilkan dari para informan sebagai pekerja di kantor KPHL (Kesatuan Pengelolaan Hutan Lindung) Kota Agung Utara, Kabupaten Tanggamus. Sumber: Wawancara pada Informan 20-24 Juli 2017

\section{Pencegahan Perambahan Hutan}

Hasil observasi dan wawancara pada 21 Juli 2017, penurunan perambah secara besarbesaran dilakukan pada tahun 2010 . Pada saat itu seluruh perambah yang masuk kawasan pekon Margomulyo diturunkan dari kawasan hutan oleh petugas gabungan TNI, Kepolisian, Polhut, Mitra Polhut dan LSM. Namun pada Januari 2017 ditemukan lahan seluas $2 \mathrm{Ha}$ (Hektar) tanaman di dalam kawasan taman nasional yang mengindikasikan bahwa masih adanya perambah hutan di dalam taman nasional. Latar belakang terbentuknya pekon Margomulyo diikarenakan masyarakat pernah menetap di dalam kawasan hutan. Aktifitas perambah hutan mereka mulai sejak tahun 1997 di era reformasi dimana era tersebut terjadinya fenomena ketidakpercayaan masyarakat terhadap pemerintah maupun terhadap para penagak hukum, sehingga mereka para perambah menganggap areal kawasan TNBBS menjadi lahan subur bagi mereka untuk melakukan penanaman. Namun sejalan dengan penataan kembali wilayah kawasan TNBBS serta upaya pelestarian kawasan, maka mereka memilih keluar karena mengetahui bahwa kawasan yang mereka tinggali adalah taman nasional.

Untuk mengurangi kegiatan perambahan maka TNBBS dan LSM (WCS, YABI,WWF) terus menerus melakukan penyuluhan dan pendekatan kepada warga. Seperti pelatihan membuat kompos, pembudidayaan tanaman musiman dan diberi bantuan kambing untuk dipelihara agar mereka tidak melakukan kegiatan di dalam taman nasional. Kegiatan ini dipimpin oleh penyuluh kehutanan.

Perkembangan lainnya untuk pencegahan perambahan hutan adalah dengan menggunakan sistem pemantauan berbasis satelit. Sistem 
ini dapat mendeteksi secara tepat kehilangan hutan dan mencegah hilangnya habitat. Joshi, A. R., Dinerstein, E., Wikramanayake, E., Anderson, M. L., Olson, D., Jones, B. S, \& Davis, C. L. (2016). Aplikasi ini dapat digunakan untuk memantau hewan yang dilindungi di kawasan itu seperti: harimau, gajah, badak dan hewan lainnya.

Pendapat informan satu dari 9 informan, menyatakan penyebab perambahan hutan adalah sebagai berikut: "Kurangnya pengetahuan para perambah akan pentingnya menjaga kelestarian hutan dan keseimbangan ekosistem. Para perambah hutan rata-rata memiliki tingkat ekonomi menengah ke bawah" (wawancara tanggal $20 \mathrm{Juli}$ 2017)

Adapun perilaku yang dapat mencegah perambaha hutan, menurut Informan ke limabelas sebagai penyuluh sebagai berikut: "Penegakan hukum secara tegas, Ikut sertanya TNI untuk pengamanannya" (wawancara tanggal 21Juli 2017)

Pendapat menjelaskan bahwa penyebab perambahan hutan adalah kurang pengetahuan untuk menjaga kelestarian alam dan keseimbangan ekosistem. Adapun mencegah terjadinya perambahan hutan dengan tindakan yang tegas dan melibatkan TNI (Tentara nasional Indonesia).

\section{SIMPULAN}

Penelitian ini dilakukan di kawasan penyangga hutan TNBBS Kabupaten Tanggamus, Indonesia. Pendekatan kualitatif interpretif adalah metode yang dianggap tepat untuk menggali data pada fenomena perambah hutan. Adapun simpulan penelitian ini adalah: Komunikasi antarpribadi mantan perambah hutan dan para tenaga pengamanan perambah hutan illegal adalah salah satu dasar dari perubahan agar perambahan hutan dapat dihentikan. Adapun komunikasi kelompok antara para tenaga pengamanan perambah hutan illegal dan para mantan perambah hutan dapat dimaksimalkan untuk pencegahan perilaku perambahan hutan tersebut. Oknum petugas akan memberitahu kepada masyarakat untuk tidak melakukan perambahan di dalam taman nasional ketika petugas akan patroli. Komunikasi 
mantan perambah hutan Taman

Nasional Bukit Barisan Selatan

menunjukkan bahwa adanya

kedekatanan antarpribadi dan belajar

menyimpang akibat sesuatu yang

dipelajari terus menerus. Ketidak

seimbangan sikap yang mendorong

melakukan penyimpangan yaitu

perambahan hutan. Penelitian ini

bersifat deskriptif kualitatif, maka

direkomendasikan untuk

mengadakan penelitian lanjutan

dengan permasalahan perambahan

hutan dari analisis keilmuan sosial

lainnya, tentu saja dengan metode

yang berbeda.

\section{DAFTAR PUSTAKA}

Deni. 2011. Analisis Perambahan Hutan Di Taman Nasional Bukit Barisan Selatan (Studi Kasus di Desa Tirom

Kecamatan Pematang Sawah Kabupaten Tanggamus. Jurnal Ilmu Kehutanan. Vol V No 1. 2011

Fahmi, Teuku \& Akbar, M zainuddin. 2015. Pemetaan Daerah Rawan Konflik Sosial di Kabupaten Tanggamus. Sosiologi, Jurnal Ilmiah Kajian Ilmu Sosial dan Budaya. Vol 17 No 22015

Handoyo, dkk. 2011. Identifikasi Tenurial Sebagai Pra-Kondisi
Untuk Implementasi Redd+ (Tenure identification as a Pre-condition for REDD+ Implementation. Jurnal elitian Sosial dan Ekonomi Kehutanan Vol. 8 No. 4 Desember 2011, $306-320$

Joshi, A. R., Dinerstein, E., Wikramanayake, E., Anderson, M. L., Olson, D., Jones, B. S., ... \& Davis, C. L. (2016). Tracking changes and preventing loss in critical tiger habitat. Science advances, 2(4), pp.1-8. https://doi.org/10.1126/sciadv. 1501675

Mulyana, Deddy .2000. Ilmu Komunikasi: Suatu Pengantar. Remaja Rosda Karya. Bandung

Proposal. 2015. Conserving Priority Habiats in The Bukit Barisan Selatan Nasional Park

Peraturan Pemerintah RI No. 68 tahun 1998 tentang Kawasan Suaka Alam dan Kawasan Pelestarian Alam (Penjelasan Undang-Undang RI No. 5 tahun 1990 pasal 16 ayat 2).

Surat pernyataan Menteri Pertanian No $\quad 7356 / M e n t a n / X / 1982$ tanggal $14 \quad$ Oktober 1982 melalui Sk Menteri Kehutanan No. 185/kpts-II/1997 tanggal $31 \quad$ Maret 1997. http://ksdae.menlhk.go.id/asset s/news/peraturan/P.17_.pdf

Walters, G., Ndjabounda, E. N., Ikabanga, D., Biteau, J. P., Hymas, O., White, L. J. T., ... 
\& Stevart, T. (2016). Periurban conservation in the Mondah forest of Libreville, Gabon: Red List assessments of endemic plant species, and avoiding protected area downsizing. Oryx, 50(3), pp. 419-430.

https://doi.org/10.1017/S00306 05315000204

Wood, Julia T. 1997. Communication In Our Lives. California:Wadsworth Publishing Company 